\title{
OUTLINES OF RUSSIAN CULTURE
}

\author{
Part II
}

Literature 


\title{
OUTLINES OF RUSSIAN CULTURE
}

\author{
Part I \\ Religion and the Church \\ Part II \\ Literature \\ Part III \\ Architecture, Painting, and Music
}




\section{OUTLINES OF \\ RUSSIAN CULTURE}

Part II

Literature

By

PAUL MILIUKOV

Edited by

MICHAEL KARPOVICH

Translated by

VALENTINE UGHET and ELEANOR DAVIS

UNIVERSITY OF PENNSYLVANIA PRESS

Philadelphia

I 942 
Copyright 1942

UNTVERSITY OF PENNSYLVANTA PRESS

Manufactured in the United States of America

\author{
London \\ Humphrey Milford \\ Oxford University Press
}

